\title{
Antibiotic sensitivity tests of various micro-organisms from poultry eggs
}

\author{
Rehana Shahnawaz Buriro ${ }^{*}$, Faiza Habib ${ }^{2}$, Rahamtullah Rind ${ }^{2}$, Mujahid \\ Ali Shah ${ }^{1,3}$, Rameez Raja Kaleri ${ }^{1}$, Abdul Khalique Samoon ${ }^{1}$, Mir Azeem \\ Talpur ${ }^{1}$ and Naqash Goswami ${ }^{1}$ \\ 1. Department of Veterinary Pharmacology, Sindh Agriculture University, 70060-Pakistan \\ 2. Department of Veterinary Microbiology, Sindh Agriculture University, 70060-Pakistan \\ 3. School of Life Science and Engineering, South West University of Science and Technology, China, Sichuan \\ Sheng, Mianyang Shi, Fucheng Qu, 青龙大道中段59号 \\ *Corresponding author's email: rsburiro@hotmail.com \\ Citation \\ Rehana Shahnawaz Buriro, Faiza Habib, Rahamtullah Rind, Mujahid Ali Shah, Rameez Raja Kaleri, Abdul \\ Khalique Samoon, Mir Azeem Talpur and Naqash Goswami. Antibiotic sensitivity tests of various micro-organisms \\ from poultry eggs. Pure and Applied Biology. Vol. 6, Issue 4, pp1417-1426. \\ http://dx.doi.org/10.19045/bspab.2017.600153
}

\begin{tabular}{llll}
\hline \hline Received: 07/09/2017 & Revised: 08/11/2017 & Accepted: 21/11/2017 & Online First: 24/11/2017 \\
\hline
\end{tabular}

\section{Abstract}

An investigation was carried on bacterial contamination of fertile and infertile poultry eggs. A total of 80 eggs, 40 from each, infertile and fertile (dead-in-shell embryo) were examined. The prevalence of bacterial species in eggs was recorded. From 40 infertile eggs, 14 (35\%) were found positive for bacterial species $22(65 \%)$ eggs were determined as negative. Nine different bacterial species were identified from infertile eggs while only 3 species were recognized from fertile eggs. The species identified from the shell samples were Staphylococcus aureus, Bacillus cerecus, Nocardia brasilienesis, Pasteurella gallinarium, Micrococcus; Bacillus subtilis, Citrobacter and Corynebacterium renale and their incidence was 20.6\%, 34.4\%, 6.8\%, 3.4\%, 24.13\%, 6.8\%, 3.4\% and $3.4 \%$ respectively. The species recognized from the egg white were Staphylococcus aureus, Escherichia coli and Micrococcus, their incidence was recorded as $28.5 \%, 14.2 \%$ and $57.14 \%$ respectively. While the species identified from egg yolk were Staphylococcus aureus and Micrococcus and their presence was as $45.45 \%$ and $54.54 \%$ respectively, the species recognized from fertile eggs were Bacillus subtilis, Staphylococcus aureus and Escherichia coli and their presence in eggs recorded as 47.6, 14.2 and 38\% respectively. All the species were tested for their susceptibility to various antibiotics. The highly active drugs against Staphylococcus aureus, Bacillus cerecus, Escherichia coli and Citrobacter species were sulphonamide and chloramphenicol and their sensitivity was recorded as 58.8, 76.4, 58.8 and 57.5\% respectively.The antibiotics against Nocardia brasielensis and Pasteurella gallinarium were Sulphonamide and gentamycin + sulphonamide with the sensitivity of 100 and 82.3\%. Corynebacterium renale was found susceptible to gentamycin, chloramphenicol and sulphonamide and their activity better than earlier drugs.

Keywords: Eggs; Antibiotics; Sensitivity tests; Micro organisms; Resistant

Introduction

Poultry plays a significant role in providing the protein in the form of meat and eggs. Eggs are the cheap source of protein. About 3261.0 million eggs are being produced and consumed in Pakistan [1]. The structure of 
egg is divided into two major portions, the shell and egg products such as liquid eggs, frozen, dried or whole whites and yolks [2]. The shell of an egg is mostly composed of calcite, a crystalline form of calcium carbonate and porous in nature. The pores are large enough to provide passage to gasses and microscopic solid particles. From these pores, the air passes through the shell to furnish oxygen to the developing embryo [3]. Normally, the oviduct of the hen is sterile; therefore the shell and internal contents of the eggs are also sterile. As the egg leaves the oviduct at a temperature of $107^{\circ} \mathrm{F}$, the shell is completely filled with yolk, white and shell membranes. During cooling, the contents shrink and the air is drawn through shell pores and form air cell Roberts [4]. The shell is always soiled with blood, manure, feathers and nest materials. Such substances are most likely contaminated with bacteria, which may draw through the shell as the egg cools. It was observed that about $5-12 \%$ of eggs are internally contaminated within few hours after they are laid. The organisms are deposited on the shell from the intestinal tract of the hen and also from other sources or the environment [5]. Eggs are the perishable commodity and can easily be spoiled by bacterial contamination. The laid egg shells probably get contaminated with a wide number of organisms from when some are pathogenic and make the egg unpleasant for consumption. The most important pathogenic bacteria are members of genus Salmonella Bacillus, Escherichia, Proteus and Pseudomonas [6]. Besides causing food poisoning; bacteria cause mortality of developing embryos in the fertile eggs. Many bacteria can kill the chicks in a shell [7]. Bacteria inside the eggs use the nutrients to multiply and produce the toxins, which are harmful to the embryos. During incubation, bacteria can prevent embryonic development; ultimately causing the embryo death [8], [9]. Keeping in view all the problems and incidences, the present study was therefore, planned to isolate bacterial organisms from fertile and non-fertile eggs and their sensitivity to different antibiotics available in the market.

Materials and methods Collection of egg samples

A total of eighty poultry eggs, forty from each fertile (Dead-in-shells embryo) and infertile were randomly collected from various farms and hatcheries In the ploythene bag which were sterilized and then were sent to Department of Veterinary Microbiology Laboratory at A.H \& Vet Faculty of Sindh Agriculture University, Tandojam and CVDL (Central Veterinary Diagnostics Laboratory Tandojam).

\section{Preparation of glassware for use Cleansing and sterilization of new glassware}

The new glassware was put in to the solution of $1 \mathrm{~N} \mathrm{HCL}$ for removing the surface of alkali and grease. The glassware was then removed from $1 \mathrm{~N}$ HCL and rinsed with 4 changes of tape and 4 changes of distilled water. Whereas glassware which were used Petri dishes, bijou's bottles, conical flask, universal bottles and all other glassware containing media and chemicals were autoclaved or boiled in an electric boiler till 1 the time of one hour and finally materials were removed and after that they were washed in wash basin that contain low concentration of (zip) liquid detergent and antiseptic (2\% savlon). After overnight soaking, all items were rinsed and brushed in the tape water, than again all material were material were rinsed with 4 changes of tape and distilled water.

Similarly used Pasteur pipettes and glassware were soaked in antiseptic detergent solution of low concentration and then dipped into the solution of (chromic acid 1\%) that any grease type material which deposited on pipettes surface during work. After overnight dipping, the pipettes were removed and washed in tap- 
water and then rinsed with distilled water. Furthermore, all the glassware were drained, placed upside down in drying oven at $55^{\circ} \mathrm{C}$ and left to dry before capping/plugging or sealing for sterilization.

\section{Sterilization}

The total petri dishes which were dried in hot oven were kept in a sterilizing box and small were wrapped in brown grease proof paper. The glass pitpet and test tubes were put with cotton plug and also were wrapped in brown grease proof paper batch of 5 to 10 . The different glassware such as centrifuge tube, conical flask, measuring cylinder were wrapped and then sealed separately with foil of aluminum. After that all glassware were kept in oven for sterilization at $165 \mathrm{C}$ temperature for 3 hours. Other glassware such aluminum and plastic caps which were sensitive to dry heat were placed in autoclave for sterilization at $121^{\circ} \mathrm{C}$ under $15 \mathrm{lb}$ pressure for 15 minutes.

\section{Media preparation}

Sensitivity of bacterial organisms to antibiotics

It provides the basis to test the sensitivity of bacteria against antibiotics. For this purpose, eight different antibiotics were used. The antibiotics were neomycin, kanamycin, ampicillin, gentamycin, chloramphenicol, sulphonamide, penicillin and tetracycline were used during this study.

Antibiotic sensitivity testing for different organism through [10] procedure with below mention material.

1. Muller Hinton agar plate $9 \mathrm{~cm}$

2. Sterile saline

3. Standard Barium Chloride

4. Sterile swab or cotton wool

5. Sterile forceps

6. Ruler

7. Sensitivity chart

8. Disc dispenser.

\section{Procedure}

During performing the test surface MullerHinton agar were dried with the help of incubator at the temperature of $37 \mathrm{C}^{0}$ for 30 min than selected and separated colonies were suspended in evenly in $4 \mathrm{ml}$ sterile normal saline solution in order to match barium chloride standard for antibiotic sensitivity. The cotton swabs were placed in the suspension than culture smeared at Muller Hinton agar surface that all surfaces of agar should be covered in suspension. Than plate was put in an incubator till 30 minutes for drying. The antibiotic Discs were kept on the agar surface with disc dispenser after pressing tightly by sterile forceps that for making it adheres with surface. After that plates were wrapped in polythene bags inverting in such a manner that middle disc can be placed in upward position inside incubator machine till 24 hours at $\left(37 \mathrm{C}^{0}\right)$ temperature. Zones of inhibition can clearly see that there were no any growth was observed round the discs. The zones of inhibition which were clear made through antibiotics against the bacterial organism were observed $\mathrm{mm}$ through the disc center with following descriptions.

The absence of clear around the disc

The clear zones with 1-2 mm $+$

The clear zones with 2 to $5 \mathrm{~mm}$ $++$

The clear zones with 5 to $10 \mathrm{~mm}$ diameter $+++$

The clear zones with 10 to $15 \mathrm{~mm}$ diameter around the disc ++++

$=$ Not sensitive

$=+$ weakly sensitive

++ Moderately sensitive

+++ Quite sensitive

++++ Highly sensitive

Results and discussion

During present study, eight different antibiotics were tested to demonstrate the susceptibility of bacterial species recognized from in-fertile and fertile poultry eggs. The results for antibiotic sensitivity tests against 
various microorganisms are presented in (Table 1, 2 \& 3), while overall results for antibiotic sensitivity tests for different microorganisms are displayed in (Graph 1).

\section{Staphylococcus aureus}

Staphylococcus aureus was quite sensitive to gentamycin and its sensitivity was recorded as $58.8 \%$. While moderately sensitive to neomycin, ampicillin and penicillin and their sensitivity against the organism was recorded as $29.4,17.64$ and $17.64 \%$ respectively. The species was noted as weakly sensitive to sulphonamide $(5.8 \%)$, but no effect of tetracycline, kanamycin and chloramphenicol against the species was recorded. All three drugs showed 0\% action against Staphylococcus aureus (Table 1).The results about antibiotic susceptibility of Staphylococcus aureus to different antibiotics used in this study are in accordance to [8], who recorded highly sensitive to gentamycin recorded as $80 \%$ but in this it was recorded as $58.8 \%$ and considered to be quite active against the species [9], further reported that Staphylococcus aureus was highly sensitive to chloramphenicol and tetracycline and their sensitivity against the species was recorded as $80 \%$ but unfortunately we recorded $0 \%$ sensitivity against the species. However, the sensitivity of Staphylococcus aureus demonstrated in this study against neomycin, ampicillin and penicillin is in line to the susceptibility recorded by [10], who recorded the sensitivity to penicillin and ampicillin as 26 and $25 \%$ respectively. The considerable difference in the susceptibility of the species to various antibiotics between the present study and to that of other workers is only might be due to host species because host species could play role to increase or decrease the susceptibility of the organism to different drugs. Otherwise there is no any reason to develop resistance in the species against the antibiotics.

\section{Bacillus cerecus}

Bacillus cerecus was observed highly sensitive to sulphonaminde, gentamycin and chloramphenicol and their degree of action against the species was recorded as 76.4, 70.5 and $64.7 \%$ respectively. The second highly active drug recorded against Bacillus cerecus during investigation was tetracycline and its action against the species measured as $58.8 \%$. The other antibiotics such as penicillin (47.0\%), ampicillin (35.2\%) neomycin $(29.4 \%)$ and kanamycin $(23.5 \%)$ were recorded as less active against Bacillus cerecus (Table 1)

[11] tested in-vitro sensitivity of Bacillus cerecus to various antibiotics recognized from mastitic milk samples of ewes and goats. He recorded highly sensitive to gentamycin $(100 \%)$ while intermediately to neomycin $(56.25 \%)$ and kanamycin $(31.25 \%)$. The other drugs used against the species showed some different degree of activity. Similar trend of sensitivity was observed by [12] who investigated in-vitro sensitivity of Bacillus species along with other bacterial isolates recovered from 44 goat mastitic samples. The species showed $100 \%$ sensitive to gentamycin while to gentamycin was $76.4 \%$ and considered being highly sensitive. The other antibiotics tested by [12] against the species were similar to the results obtained for the drugs used against the Bacillus cerec us during this study. However, the results of the present study about antibiotic sensitivity against Bacillus cerecus recorded are in accordance to the above workers, they also recorded similar results as recorded in this investigation. 
Table 1. Antibiotic sensitivity of various organisms isolated and identified from poultry

\begin{tabular}{|c|c|c|c|c|c|}
\hline $\begin{array}{l}\text { Bacterial } \\
\text { species }\end{array}$ & Antibiotic discs used & $\begin{array}{l}\text { Zone } \\
\text { around } \\
\text { discs } \\
(\mathrm{mm})\end{array}$ & $\begin{array}{l}\text { Indication } \\
\text { of } \\
\text { sensitivity }\end{array}$ & $\begin{array}{l}\text { Sensitivity } \\
\text { percentage }\end{array}$ & $\begin{array}{l}\text { Degree of } \\
\text { sensitivity }\end{array}$ \\
\hline $\begin{array}{l}\text { Staphylococcus } \\
\text { aureus }\end{array}$ & $\begin{array}{l}\text { Tetracycline (TE) } \\
\text { Gentamycin (CN-30) } \\
\text { Sulphonamide (S-3) } \\
\text { Neomycin (N-10) } \\
\text { Kanamycin (K-5) } \\
\text { Ampicillin (Amp) } \\
\text { Penicillin (P-5) } \\
\text { Chloramphenicol (C- } \\
\text { 30) }\end{array}$ & $\begin{array}{l}0 \mathrm{~mm} \\
10 \mathrm{~mm} \\
1 \mathrm{~mm} \\
5 \mathrm{~mm} \\
0 \\
3 \mathrm{~mm} \\
3 \mathrm{~mm} \\
0 \mathrm{~mm}\end{array}$ & $\begin{array}{l}- \\
+++ \\
+ \\
++ \\
- \\
++ \\
++ \\
-\end{array}$ & $\begin{array}{l}0 \\
58.8 \\
5.8 \\
29.4 \\
0 \\
17.64 \\
17.64 \\
0\end{array}$ & $\begin{array}{l}\text { Not sensitive } \\
\text { Quite sensitive } \\
\text { Weakly } \\
\text { sensitive } \\
\text { Moderately } \\
\text { sensitive } \\
\text { Not sensitive } \\
\text { Moderately } \\
\text { sensitive } \\
\text { Moderately } \\
\text { sensitive } \\
\text { Not sensitive }\end{array}$ \\
\hline $\begin{array}{l}\text { Bacillus } \\
\text { cerecus }\end{array}$ & $\begin{array}{l}\text { Tetracycline (TE) } \\
\text { Gentamycin (CN-30) } \\
\text { Sulphonamide (S-3) } \\
\text { Neomycin (N-10) } \\
\text { Kanamycin (K-5) } \\
\text { Ampicillin (Amp) } \\
\text { Penicillin (P-5) } \\
\text { Chloramphenicol (C- } \\
\text { 30) }\end{array}$ & $\begin{array}{l}10 \mathrm{~mm} \\
12 \mathrm{~mm} \\
13 \mathrm{~mm} \\
5 \mathrm{~mm} \\
4 \mathrm{~mm} \\
6 \mathrm{~mm} \\
8 \mathrm{~mm} \\
11 \mathrm{~mm}\end{array}$ & $\begin{array}{l}+++ \\
++++ \\
++++ \\
++ \\
++ \\
+++ \\
+++ \\
++++\end{array}$ & $\begin{array}{l}58.8 \\
70.5 \\
76.4 \\
29.4 \\
23.5 \\
35.2 \\
47.0 \\
64.7\end{array}$ & $\begin{array}{l}\text { Quite sensitive } \\
\text { Highly sensitive } \\
\text { Highly sensitive } \\
\text { Moderately } \\
\text { sensitive } \\
\text { Moderately } \\
\text { sensitive } \\
\text { Quite sensitive } \\
\text { Quite sensitive } \\
\text { Highly sensitive }\end{array}$ \\
\hline
\end{tabular}

\section{Escherichia coli}

Generally, the species showed least sensitivity to many drugs tested against it. Only the antibiotics chloramphenicol and gentamycin were recorded as quite active against Escherichia coli and their activity against the species measured as 58.8 and $47.0 \%$ respectively (Table 2 ). The drugs observed moderately active against the species were kanamycin, tetracycline and neomycin and their percentage of sensitivity is also presented in the same (Table 2). While the other drugs such as sulphanomide, ampicillin and penicillin were failed to inhibit the growth of the organism on agar plate and recorded as $0 \%$ active against Escherichia coli. It is concluded from the investigation that the species recognized from the other host species previously was highly sensitive to majority of the drugs tested against the species during present study. However, only one or two antibiotics showed quite active role but failed to show highly active against the species. [8], studied the antibiotic sensitivity of Escherichia coli recognized from the uteri of goats and observed highly sensitive to gentamycin and chloramphenicol and susceptibility was recorded as 80.0 and $73.3 \%$ respectively. The other drugs observed ineffective against the species were tetracycline, sulphamethoxazole and ampicillin and showed $0 \%$ action against the above species. [13] assessed the susceptibility of Escherichia coli by 14 different antibiotics through the disk diffusion technique and found tetracycline most ineffective drug against the Escherichia coli. Therefore the 
results of the present investigation do agree with the findings of the above authors. The present findings also agree with the results of [14-17], who found the Escherichia coli

Table 2. Antibiotic sensitivity of various organisms isolated and identified from poultry eggs

\begin{tabular}{|c|c|c|c|c|c|}
\hline $\begin{array}{l}\text { Bacterial } \\
\text { species }\end{array}$ & Antibiotic discs used & $\begin{array}{l}\text { Zone } \\
\text { around } \\
\text { discs } \\
(\mathbf{m m})\end{array}$ & $\begin{array}{l}\text { Indication } \\
\text { of } \\
\text { sensitivity }\end{array}$ & $\begin{array}{l}\text { Sensitivity } \\
\text { percentage }\end{array}$ & $\begin{array}{l}\text { Degree of } \\
\text { sensitivity }\end{array}$ \\
\hline $\begin{array}{l}\text { Escherichia } \\
\text { coli }\end{array}$ & $\begin{array}{l}\text { Tetracycline }(\mathrm{TE}) \\
\text { Gentamycin }(\mathrm{CN}-30) \\
\text { Sulphonamide }(\mathrm{S}-3) \\
\text { Neomycin } \quad(\mathrm{N}-10) \\
\text { Kanamycin }(\mathrm{K}-5) \\
\text { Ampicillin } \quad(\mathrm{Amp}) \\
\text { Penicillin (P-5) } \\
\text { Chloramphenicol(C-30) }\end{array}$ & $\begin{array}{l}4 \mathrm{~mm} \\
8 \mathrm{~mm} \\
0 \mathrm{~mm} \\
3 \mathrm{~mm} \\
5 \mathrm{~mm} \\
0 \mathrm{~mm} \\
0 \mathrm{~mm} \\
10 \mathrm{~mm}\end{array}$ & $\begin{array}{l}++ \\
+++ \\
- \\
++ \\
++ \\
- \\
- \\
+++\end{array}$ & $\begin{array}{l}23.5 \\
47.0 \\
0 \\
17.64 \\
29.4 \\
0 \\
0 \\
58.8\end{array}$ & $\begin{array}{l}\text { Moderately } \\
\text { sensitive } \\
\text { Quite sensitive } \\
\text { Not sensitive } \\
\text { Moderately } \\
\text { sensitive } \\
\text { Moderately } \\
\text { sensitive } \\
\text { Not sensitive } \\
\text { Not sensitive } \\
\text { Quite sensitive }\end{array}$ \\
\hline $\begin{array}{l}\text { Nocardia } \\
\text { brasielensis }\end{array}$ & 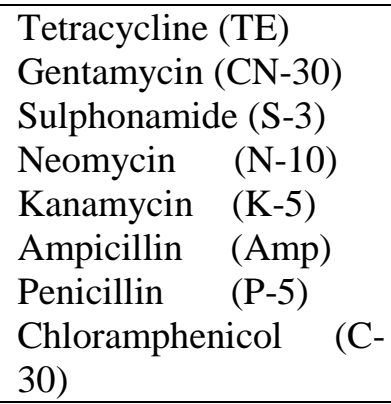 & $\begin{array}{l}10 \mathrm{~mm} \\
15 \mathrm{~mm} \\
17 \mathrm{~mm} \\
9 \mathrm{~mm} \\
8 \mathrm{~mm} \\
0 \mathrm{~mm} \\
0 \mathrm{~mm} \\
0 \mathrm{~mm}\end{array}$ & $\begin{array}{l}+++ \\
++++ \\
++++ \\
+++ \\
+++ \\
- \\
- \\
-\end{array}$ & $\begin{array}{l}58.8 \\
88.2 \\
100 \\
52.9 \\
47.0 \\
0 \\
0 \\
0\end{array}$ & $\begin{array}{l}\text { Quite sensitive } \\
\text { Highly sensitive } \\
\text { Highly sensitive } \\
\text { Quite sensitive } \\
\text { Quite sensitive } \\
\text { Not sensitive } \\
\text { Not sensitive } \\
\text { Not sensitive }\end{array}$ \\
\hline $\begin{array}{l}\text { Pasteurella } \\
\text { gallinarium }\end{array}$ &  & $\begin{array}{l}8 \mathrm{~mm} \\
14 \mathrm{~mm} \\
14 \mathrm{~mm} \\
6 \mathrm{~mm} \\
2 \mathrm{~mm} \\
2 \mathrm{~mm} \\
2 \mathrm{~mm} \\
5 \mathrm{~mm}\end{array}$ & $\begin{array}{l}+++ \\
++++ \\
++++ \\
+++ \\
++ \\
++ \\
++ \\
++\end{array}$ & $\begin{array}{l}47.0 \\
82.3 \\
82.3 \\
35.2 \\
11.7 \\
11.7 \\
11.7 \\
29.4\end{array}$ & $\begin{array}{l}\text { Quite sensitive } \\
\text { Highly sensitive } \\
\text { Highly sensitive } \\
\text { Quite sensitive } \\
\text { Moderately } \\
\text { sensitive } \\
\text { Moderately } \\
\text { sensitive } \\
\text { Moderately } \\
\text { sensitive } \\
\text { Moderately } \\
\text { sensitive }\end{array}$ \\
\hline
\end{tabular}

\section{Nocardia brasiliensis}

The sensitivity of various antibiotics against Nocardia brasilensis was tested and is presented in (Table 2). Sulphonamide and gentamycin were recorded as the most effective drugs and showed 100 and $88.2 \%$ resistant to tetracycline, sulphamethoxazole and ampicillin while sensitive to chloramphenicol. 
carried-out in-vitro antibiotic susceptibility to Nocardia brasilienesis and measured 80 , 60 , and $100 \%$ sensitivity to gentamycin, tetracycline and sulphmethoxazole/ trimethoprim respectively. Furthermore, [18] recorded Nocardia species was found highly sensitive to gentamycin and tetracycline during present study. Therefore, the results regarding the sensitivity of Nocardia brasilienesis to various antibiotics observed in this study are in agreement to the findings of above workers.

\section{Pasteurella gallinarium}

The species Pasteurella gallinarium was tested to record its susceptibility against different antibiotics and found highly sensitive to gentamycin and sulphonamide. The susceptibility of the species against these two antibiotics was $82.3 \%$. While tetracycline was observed as quite active against Pasteurella gallinarium. The other drugs were found moderately effective against the species are given in (Table 2). Generally, majority of the drugs showed a least active role against the species. Only two drugs those were mentioned earlier found highly effective against the species. [15], carried-out antibiotic sensitivity on different bacterial organisms instead of Pasteurella gallinarium, the species Pasteurella multocida was found highly sensitive to gentamycin only but we recorded the same antibiotic against Pasteurella gallinarium. Therefore, the present results regarding the sensitivity to gentamycin are comparable to above workers because of only species difference otherwise the genus was same. So one should expect that the gentamycin could work against Pasteurella gallinarium. Furthermore, our results do agree in general with the results of [8], who recorded the organism Pasteurella multocida was quite sensitive to gentamycin and its action against the species was recorded as $66.6 \%$, which is quite close to our findings against Pasteurella gallinarium. The other antibiotics tested by [8], against Pasteurella multocida but not Pasteurella gallinarium are in partial agreement to that of present findings about antibiotic susceptibility of the species to different drugs observed in this investigation.

\section{Citrobacter species}

The sensitivity percentage of the Citrobacter species to antibiotics is given in (Table 3). The species was recorded as highly sensitive to gentamycin with the sensitivity of $57.5 \%$. The species was quite sensitive to neomycin and its sensitivity recorded as $41.17 \%$ and next was chloramphenicol with the sensitivity of $47.0 \%$. The organism was found moderately sensitive to kanamycin with $29.4 \%$ sensitivity. The organism was recorded as resistant to penicillin, ampicillin, tetracycline and sulphonamide with $0 \%$. [15] demonstrated the antibiotic sensitivity of Citrobacter species recovered from poultry feed and found highly sensitive to pipemidic acid with its sensitivity of $87.5 \%$. While second highly active drug against the species was cefuroxine $(68.75 \%)$. At the same time the quite sensitive antibiotic against Citrobacter species was recorded as cefpodoxime $(62.5 \%)$. Moderately active antibiotics recorded were cefoperazone and erythromycin and their sensitivity level against organism observed as 50 and $37.5 \%$ respectively. The antibiotics used and the susceptibility recorded against the species in this study are not comparable to the values observed by [19], who used some different antibiotics those were not used against the Cirobacter species during present study. Therefore, our findings about the susceptibility of Citrobacter to various antibiotics are different from the above author, but the pattern of sensitivity is similar to that of [20], recorded for Citrobacter species.

\section{Corynebacterium renale}

Corynebacterium renale was recorded as highly sensitive to gentamycin, 
sulphonamide and chloramphenicol with the sensitivity of $88.23,88.23$ and $88.23 \%$ respectively. Whereas penicillin and tetracycline were recorded as next highly active drug and their sensitivity against the species was recorded as 70.5 and $56.8 \%$ respectively. The quite active antibiotic observed was ampicillin and its efficacy recorded as $52.9 \%$ against the above species. The organism was moderately sensitive to kanamycin with susceptibility of $29.5 \%$ while weakly sensitive to neomycin $(5.8 \%)$. $[19,21,22]$ reported that Corynebacterium diphtheriae and Corynebacterium pyogenes

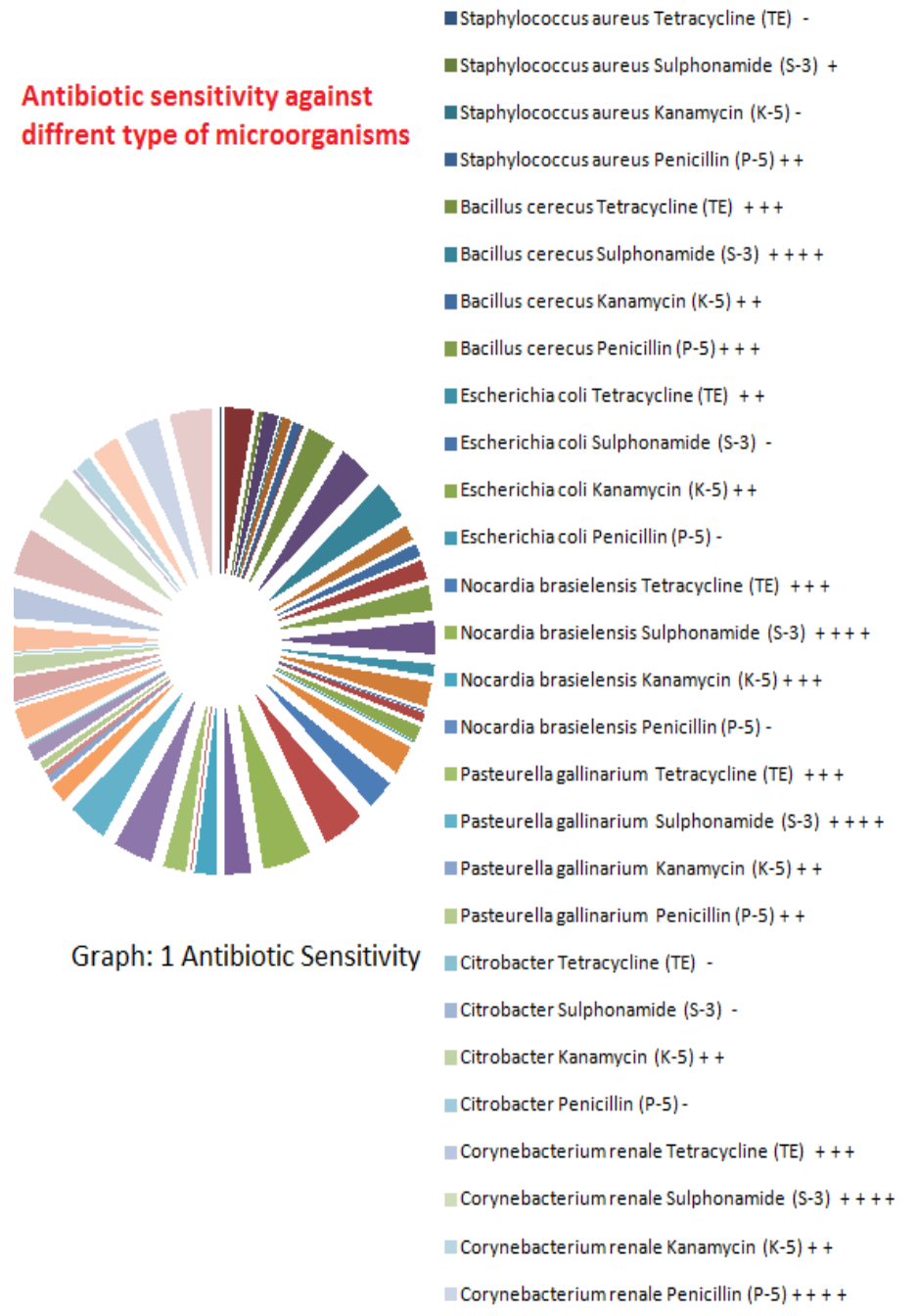

were highly sensitive to gentamycin, kanamycin, chloramphenicol, tetracycline a Sulphamethoxozole. [21], demonstrated similar kind of susceptibility during his investigation. He found Corynebacterium pyogenes as highly sensitive to kanamycin, neomycin and sulfamethoxazole trimethoprim and their efficacy against the species was recorded as $100 \%$. However, penbritin, penicillin and ampicillin were recorded likely to be moderate in their action against the organism and measured as 83.3, 65.6 and $66.6 \%$ respectively.

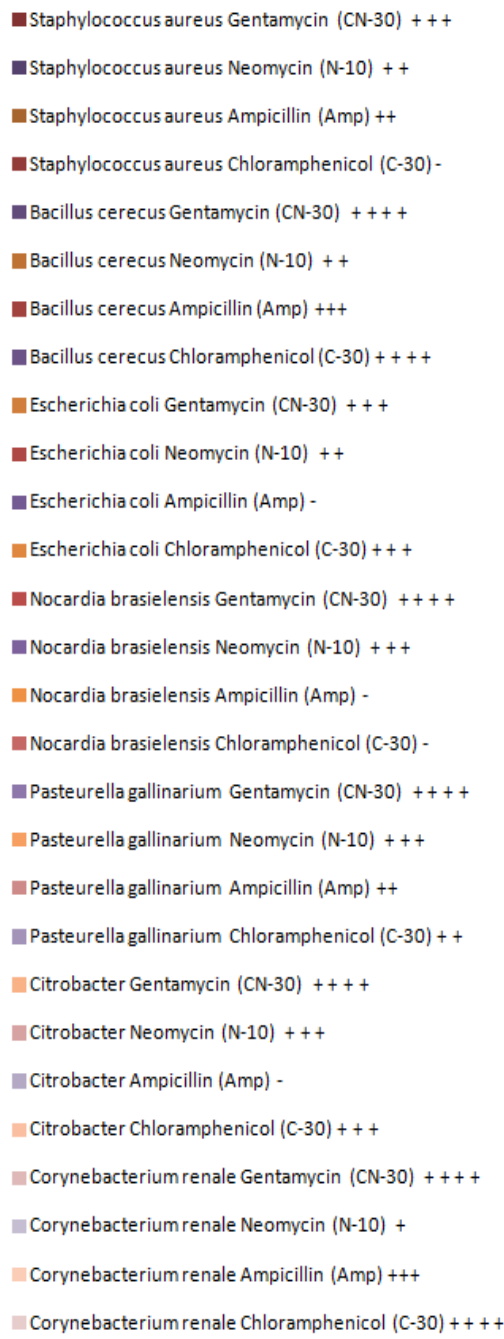

\section{Graph 1.}

The overall results for antibiotic sensitivity for different species of bacteria identified from poultry eggs to different antibiotics are summarized in single graph presentation 
Table 3. Antibiotic sensitivity of various organisms isolated and identified from poultry eggs

\begin{tabular}{|c|c|c|c|c|c|}
\hline $\begin{array}{l}\text { Bacterial } \\
\text { species }\end{array}$ & Antibiotic discs used & $\begin{array}{l}\text { Zone around } \\
\text { discs }(\mathrm{mm})\end{array}$ & $\begin{array}{l}\text { Indication } \\
\text { of sensitivity }\end{array}$ & $\begin{array}{l}\text { Sensitivity } \\
\text { percentage }\end{array}$ & $\begin{array}{l}\text { Degree of } \\
\text { sensitivity }\end{array}$ \\
\hline Citrobacter & 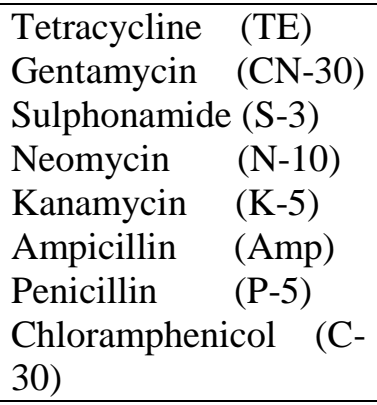 & $\begin{array}{l}0 \mathrm{~mm} \\
12 \mathrm{~mm} \\
0 \mathrm{~mm} \\
7 \mathrm{~mm} \\
5 \mathrm{~mm} \\
0 \mathrm{~mm} \\
0 \mathrm{~mm} \\
8 \mathrm{~mm}\end{array}$ & $\begin{array}{l}- \\
++++ \\
- \\
+++ \\
++ \\
- \\
- \\
+++\end{array}$ & $\begin{array}{l}0 \\
57.5 \\
0 \\
41.17 \\
29.4 \\
0 \\
0 \\
47.0\end{array}$ & $\begin{array}{l}\text { Not sensitive } \\
\text { Highly sensitive } \\
\text { Not sensitive } \\
\text { Quite sensitive } \\
\text { Moderately } \\
\text { sensitive } \\
\text { Not sensitive } \\
\text { Not sensitive } \\
\text { Quite sensitive } \\
\end{array}$ \\
\hline $\begin{array}{l}\text { Corynebact } \\
\text { erium } \\
\text { renale }\end{array}$ & 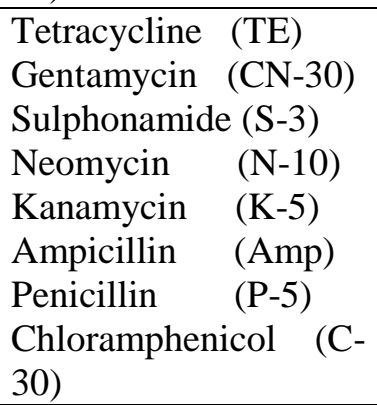 & $\begin{array}{l}10 \mathrm{~mm} \\
15 \mathrm{~mm} \\
15 \mathrm{~mm} \\
1 \mathrm{~mm} \\
5 \mathrm{~mm} \\
9 \mathrm{~mm} \\
12 \mathrm{~mm} \\
15 \mathrm{~mm}\end{array}$ & $\begin{array}{l}+++ \\
++++ \\
++++ \\
+ \\
++ \\
+++ \\
++++ \\
++++\end{array}$ & $\begin{array}{l}56.8 \\
88.23 \\
88.23 \\
5.8 \\
29.4 \\
52.9 \\
70.5 \\
88.23\end{array}$ & $\begin{array}{l}\text { Quite sensitive } \\
\text { Highly sensitive } \\
\text { Highly sensitive } \\
\text { Weakly sensitive } \\
\text { Moderately } \\
\text { sensitive } \\
\text { Quite sensitive } \\
\text { Highly sensitive } \\
\text { Highly sensitive }\end{array}$ \\
\hline
\end{tabular}

Absence of clear zone around disk -

Clear zone with $1-2 \mathrm{~mm}+$

Clear zone with $2-5 \mathrm{~mm}$ diameter ++
Clear zone with $5-10 \mathrm{~m}$

Clear zone with $10-15 \mathrm{~mm}$ diameter +++

\section{Conclusions}

From the present investigation, it is observed that bacterial contamination in both, infertile and fertile (dead in-shell embryo) eggs are common. The higher prevalence of bacterial species was recorded in yolk as compared to albumin. A weak correlation between shell and internal content of the egg with bacterial contamination was recorded. The higher incidence of bacterial species recorded in yolk and albumen of egg was Micrococcus sp. while in fertile (dead in- shell embryo) was Bacillus subtilis. The highly active drugs against majority of bacterial species were found gentamicin and neomycin.

\section{Authors' contributions}

Conceived and designed the experiments: RS Buriro \& RR Rind, Performed the experiments: RS Buriro \& Faiza Habib, MA Shah \& RR Kaleri Data: G Naqash \& MA Talpur, Wrote the paper: RS Buriro \& RR Kaleri.

\section{References}

1. Anonymous (2001). Economic survey of Pakistan. Economic Advisory Wing, Finance Division Islamabad.

2. Frobisher Crabtree and Good Heart (1984). Fundamentals of Microbiology. $9^{\text {th }}$ Edi. W.B Saunders Company, London. pp. 753-754.

3. Salle AJ (1988). Fundamental Principles of Bacteriology. $7^{\text {th }}$ Ed. Tata McGrawHill Publishing Company Limited, 4/12 Asaf Ali Road. New Delhi., pp. 773-776

4. Andrew (2005). Eggs and egg products." Micro-Organisms in Foods 6. Springer US, 597-642.

5. De K (2008). Bacterial contamination of table eggs and the influence of housing systems. World's poultry science journal 64 (1): 5-19.

6. Bell BA (2004). "Low reproductive success of leatherback turtles, Dermochelys coriacea, is due to high 
embryonic mortality. Biological Conservation 115(1): 131-138.

7. Alba D, Liliana M \& Shawkey D (2015). Mechanisms of antimicrobial defense in avian eggs. Journal of Ornithology 156(1): 399-408.

8. Mirza A, Ashfaque M, Iftikhar H (1999). Bacteriology of dead-in-shell broiler embryos and antibiotic sensitivity of the isolates. Pak J Biol Sc 2(2):442-444

9. Fatma AM, Bastawrows AF, Abd-ELGawad AM \& Nawal GK (2001). Bacteriological studies on the causation of low hatchability and infertility of quail eggs in Assiut Governorate. Assiut Vet Med J 44(88): 257-274

10. Araujo MLC \& Andrioli JL (1996). Staphylococcus aureus: resistance patterns to antimicrobials and penicillinase among strains isolated from apparently healthy lactating cows. Revista de-Microbiologia 27: 60-63

11. Shaikh SN (1999). Bacteriological studies on the uteri of slaughtered goats. M.Sc (Hons) thesis, Department of Veterinary Microbiology, Sindh Agriculture University, Tando Jam, Pakistan.

12. Dewani P (2000). Bacteriological studies on mastitis in ewes and goats. M.Sc (Hons) thesis, Department of Veterinary Microbiology, Sindh Agriculture University, Tando Jam.

13. Mishra PR, Hazari S, Pal A \& Hazari S (1996). Subclinical mastitis in goats with special reference to fungus. Ind $J$ Dairy Sci 49(3): 209-210

14. Rind R and Khan TS (2001). Antibiogram sensitivity of bacterial organisms identified from surgical and non-surgical wounds of animals. Pak $J$ Biol Sci 3(10): 1729-1723
15. Mehrotra PK, Lakhotia RL, Mehrotra PN (1984). Occurrence of serotypes and antibiotic resistance in Escherichia coli isolates from different species. Ind $J$ Anim Sci 54: 396-399

16. Rao VP (1996). Veterinary Systematic Bacteriology and Pathogenic Fungi. CB. Publisher and Distributors New Delhi, India. pp. 1-12

17. Burrows GE, Milne $\mathrm{J} \&$ Schlundt $\mathrm{J}$ (1989). Antibiogram for bacterial pathogens isolated at Veterinary Research Laboratory. Zimbabwe Vet J 20: 53-70.

18. Ishimaru M, Endoh YS \& Yoshimura $\mathrm{H}$ (1996). Drug resistance of strains of Escherichia coli, Salmonella and Staphylococcus aureus isolated from domestic animals during the period 1992-1994 in Japan. Ann Rept Nat Vet Assay Lab No. 33: 1-20

19. Good Fellow M \& Orchard (1974). Antibiotic sensitivity to some coli form bacteria and its value as a criterian for taxonomy. J Gen Microb 83: 375-387.

20. Sajida PK (2000). Isolation of bacterial organisms from commercial broiler feeds. M.Sc (Hons) thesis, Department of Veterinary Microbiology, Sindh Agriculture University, Tando Jam, Pakistan.

21. Rind R \& Khan TS (2000). Antibiogram sensitivity of bacterial organisms identified from surgical and non-surgical wounds of animals. Pak J Biol Sci 3(10): 1729-1723.

22. Nizamani AW (1999). Studies on the bacterial flora of uteri of slaughtered sheep. M.Sc. thesis, Department of Veterinary Microbiology, Sindh Agricul. Univ., Tando Jam. 